\title{
An Analysis of the Sustainability Disclosures of Textile and Apparel Companies in Turkey
}

\author{
Ebru Saygili ${ }^{1}$, Arikan Tarik Saygili ${ }^{2}$, Seher Goren Yargi ${ }^{1}$ \\ ${ }^{1}$ Yasar University, Faculty of Business, Department of International Trade and Finance, 35100 Bornova, Izmir, Turkey \\ ${ }^{2}$ Izmir University of Economics, Department of Business Administration, 35530 Balcova, Izmir, Turkey
}

Corresponding Author: Ebru Saygili, ebru.esendemir@yasar.edu.tr

\begin{abstract}
The aim of this study is to discuss recent sustainability developments in the textile industry and to explore the disclosures of textile and apparel companies in Turkey. The economic, environmental and social sustainability disclosures of 34 companies were analyzed in relation to Global Reporting Initiative (GRI) standards. The results of the analysis revealed that the most frequently mentioned sustainability issues were related to employees, water, product, market, supplier, education, economic, energy and waste. A majority of companies provided economic disclosures about economic performance and anti-competition; environmental disclosures about water and effluents and energy; and social sustainability disclosures about training, education, employment, health and safety, diversity and equal opportunity, marketing and labeling.
\end{abstract}

\author{
ARTICLE HISTORY \\ Received: 16.10 .2018 \\ Accepted: 30.04.2019

\section{KEYWORDS} \\ Textile and apparel industry, \\ sustainability disclosures, \\ economic sustainability, \\ environmental sustainability, \\ social sustainability, GRI
}

\section{INTRODUCTION}

Global warming and other climate changes alongside rising scarcity of natural resources due to increasing population, mass production and consumption needs have promoted more prominent sustainability practices in the textile and apparel industry as it has had in other sectors. Additionally, sensitivity and the demands of an increasing number of environmentally conscious consumers in markets can be expected to significantly affect sustainability applications. Realizing the importance of sustainability Turkish Clothing Manufacturers published Ufuk 2030 in April 2016 in order to inform and guide companies in Turkish textile and apparel industry. Some of these foreseeable effects of sustainability, for textile and apparel manufacturers, can be summarized briefly under five main categories: raw materials, production, supply chain, standards, and regulations and brands [1]. i. Raw Materials: Textile manufacturers prefer natural raw materials, such as cotton and linen, as they are considered healthier. However, obtaining them requires the consumption of precious natural resources, such as water. Global irrigation of cotton fields consumes approximately $2.6 \%$ of the Earth's annual water resources, which significantly increases the risk of drought, especially in Central Asia. Additionally, artificial fertilizers and pesticides have long-lasting harmful effects on the environment. Therefore, the Better Cotton Standard has been developed for more responsible farming, including every step in cotton production, from sowing and growing to picking and harvesting [2]. This standard is used by various international brands in their supply chains, including Adidas, H\&M, IKEA, Levi Strauss \& Co., M\&S and Nike. Accordingly, the use of cotton in the textile industry is expected to drop to $18.5 \%$ in 2030 from $38 \%$ in 2008 whereas the share of polyester is expected to rise to $61 \%$ in 2030 from $36.6 \%$ in 2008 [1].

To cite this article: Saygili E, Saygili, AT, Yargi SG. 2019. An analysis of the sustainability disclosures of textile and apparel companies in Turkey Tekstil ve Konfeksiyon 29(3), 189-196. 
ii. Production: Many chemicals are used throughout the textile manufacturing process. Natural raw materials and products require washing before, during and/or at the end of the production cycle, which cause significant unproductive water consumption and significant amounts of effluent water. Manufactured fibers use less water, although they produce greater greenhouse gas emissions [3]. Moreover, manufactured fibers are recyclable, which can reduce the unproductive consumption of natural resources and significantly reduce industrial waste. Sustainability concerns and practices have also shifted scientific studies and technology for the textile and apparel industry [4]. Authorities in the textile and apparel industry globally are striving to create a new foundation by increasing competitiveness and efficiency in operational activities, including resource utilization, as well as by promoting social and environmental consciousness. As a result, changes are expected in consumer preferences towards more environment-friendly renewable and recyclable products. Fibers and fabric recycling can be used in numerous applications, such as soil reinforcement, filtration systems, compositing, acoustics and building insulation [5]. Fashion authorities and society in general are expected to demand a slower pace in fashion trends in the future in order to promote longer use of products and second-hand product consumption. Clothes are being reused in a growing number of ways, such as repurposing as fancy dress or dusters, selling, exchanging and donating [5].

iii. Supply Chain: Working with local suppliers when possible is expected to be one of the most important factors in supplier selection as it offers several benefits. Firstly, it minimizes transportation distances, which decreases carbon emissions. Secondly, it is easier to obtain improved transparency and monitoring practices in supplier relations. Nevertheless, geographical distance is not the only factor to consider while selecting supplies. First, the required supplies may not be available from local suppliers or they may not be sufficiently sensitive about sustainability practices and/or eager to adopt them. Second, the prices offered by local suppliers may not be favorable and compromised solely for the purpose of sustainability. Finally, building sustainable relationships that promote transparency and continuous cooperation may not be possible with local suppliers. However, it is possible to integrate operations through current information technology in order to improve mutual transparency and control applications with suppliers. Thus, the Sustainable Apparel Coalition, a cross-brand initiative, developed its Higg Index for evaluating fiber and fabric efficiency, and improve supply chain performance industry-wide [4, 6]. Applying the most suitable approaches when working with suppliers worldwide, such as preferring rail transportation over alternatives whenever possible, can contribute both to more efficient resource use and to further improvements in operational efficiency and reduced carbon emissions. iv. Standards and Regulations: The number and scope of standards and regulations aiming to enhance sustainability practices has been increasing continuously. As people become more knowledgeable, they become more sensitive and environmentally conscious while legal authorities, foreseeing the consequences of socially and environmentally irresponsible behavior, continue to set more and stricter standards, and expand the scope of relevant laws and regulations. Standards and regulations, especially in the areas of worker and workplace safety, energy consumption, carbon emissions and waste management, are expected to become critical for sustainability in the textile industry, as in other sectors.

v. Brands: Textile and apparel retailers play very important roles due to their ability to create and improve consumer awareness of sustainability, and to influence their opinions and preferences [7, 8]. In their future sustainability practices, companies aiming at greater brand recognition and customer loyalty are expected to act with great responsibility to promote these practices in the following areas:

\section{- Manufacturing and servicing cycles}

- Selection of suppliers and raw materials

- Design of product and production processes

- Worker and work place safety

- Social and environmental consciousness

- Selection of methods for transportation, presentation/ packaging and sale of products

- Monitoring consumption and promoting recycling/ renewing practices of both raw material and products

This study discusses recent sustainability trends in textiles by analyzing the economic, environmental and social sustainability disclosures of textile and apparel companies in Turkey. Specifically, the economic, environmental and social sustainability disclosures of 34 companies were analyzed in relation to the Global Reporting Initiative (GRI) using content analysis.

\section{LITERATURE REVIEW}

The most widely-used definition of sustainable development is that introduced by the World Commission on Environment and Development (1987) as “development that meets the needs of the present without compromising the ability of future generations to meet their own needs" [9]. Previous studies of the textile industry in Turkey have included sustainable textile production [10], and waste management and recycling [11-13]. According to Eser et al. [12], sustainability practices in fashion should consider product life cycle designs with creative ideas and applications in the areas of product design, production, logistics, retailing, usage and recycling. Accordingly, 
product life cycle design is favored in sustainability applications rather than product design. Furthermore, to achieve sustainability in the textile industry, efforts should focus on $3 \mathrm{R}$ and $4 \mathrm{R}$ concepts, whereby $4 \mathrm{R}$ adds rebuy to reuse, reduce and recycle, as previously suggested by the $3 \mathrm{R}$ approach. 4R emphasizes the importance of rebuying products already produced by reusable and/or recyclable material. Ar and Tokol [14] claim that well-organized and successfully-applied environmental and social sustainability practices generate greater benefits, such as increased operational efficiency and profitability, improved perceptions of company image, corporate trust, brand and customer loyalty in the market, increased ability to recruit better-qualified staff, improved employee satisfaction and organizational commitment, improved shareholder satisfaction, and generating more diverse and favorable financing alternatives. Despite these advantages, Kusku [15] found that Turkish textile companies do not generally seem to have an organizational structure for conducting environmental social sustainability activities. Instead, because they perceive environmental sustainability activities as cost-raising factors, they conduct them through quality coordination departments.

Since the 1990s, a growing number of companies have issued voluntary sustainability disclosures, including those in the textile and apparel industry [16, 17]. These disclosures address issues concerning the economic, environmental and social dimensions of corporate performance [18, 19]. Kamal and Deagan [16], for example, found increasing disclosure of social and environmental governance information in Bangladesh's textile and garment companies' annual reports from 1996 to 2009. They argued that the reason for this increase was to satisfy powerful stakeholders, such as global textile and clothing companies. Kozlowski et al. [17] identified reported indicators in corporate sustainability reports, other documents and web sites of 14 apparel brands belonging to the Sustainable Apparel Coalition (SAC).

The Global Reporting Initiative's (GRI) sustainability reporting guidelines [20], developed through the involvement of multiple stakeholders, appear to be the most widely accepted and influential among companies globally [21]. GRI standards aim to create a common language for organizations and stakeholders regarding economics, environmental and social issues. Various researchers have investigated the GRI sustainability indicators disclosed by different industries [22] across countries including Canada [19], Netherlands [23], Spain [24] and Greece [25]. They found several trends in the results. Overall, for instance, economic indicators focusing on financial issues, environmental indicators focusing on energy and water, social indicators focusing on labor practices were widely reported [19]. Furthermore, the indicators reported, and their frequency varied across industries. The present study provides one of the first analyses of the GRI indicators used in corporate sustainability reports in the textile and apparel industry in Turkey.

\section{MATERIAL AND METHOD}

This study analyzes the sustainability performance of the Turkish textile and apparel industry in terms of the GRI sustainability indicators. The research question investigated is: "What GRI sustainability indicators are currently being disclosed by Turkish textile and apparel companies in Turkey?" The disclosures of the companies were analyzed using content analysis, which has been widely used in previous studies investigating sustainability reports $[16,17$, $19,23]$. The analysis is based on determining the presence or absence of particular information in a given subject [23, 26]. The intent of the analysis here was to identify all the GRI sustainability indicators reported by companies. The sample was chosen from textile and apparel companies listed in Turkey's Top 500 Industrial Enterprises 2017 Survey [27] and Borsa Istanbul Textile and Leather Index XTEKS [28]. Among 184 textile and apparel companies, $34(18 \%)$ issued sustainability disclosures. Data was collected from recent disclosures in the companies' sustainability reports, corporate social responsibility (CSR) reports, annual reports and corporate websites, as summarized in Table 1.

Table 1. Distribution of sustainability disclosure types from Turkish textile and apparel companies

\begin{tabular}{lc}
\hline Sources of sustainability disclosures & No. of companies \\
\hline Sustainability reports & 9 \\
Corporate social responsibility reports & 1 \\
Annual reports & 12 \\
Websites & 12 \\
Total & 34 \\
\hline
\end{tabular}

Table 2 presents the breakdown of the international standards used by the selected companies. A majority use ISO as their quality certificate, followed by GRI and OEKO-TEX, while 16 companies adopted the GRI sustainability standards.

Table 2. International quality certificates and standards adopted by Turkish textile and apparel companies*

\begin{tabular}{ll}
\hline $\begin{array}{l}\text { International quality certificate } \\
\text { and standard }\end{array}$ & No. of companies \\
\hline ISO & 24 \\
GRI & 16 \\
OEKO-TEX & 13 \\
OHSAS & 11 \\
GOTS & 6 \\
USTER & 2 \\
BELCORO & 2 \\
CERES & 1 \\
ISPA & 1 \\
LEED & 1 \\
GLOBAL GAP CERTIFICATE & 1 \\
\hline
\end{tabular}

* Descriptions of the abbreviations are given in Appendix 1. 
To provide a basis for the content analysis, keywords were identified from GRI topic-specific standards related to economic, social and environment issues. The frequency counts of keywords and frequency analysis, shown in Table 3, were collected using dictionary-based NVivo software, thereby eliminating errors from multiple inputs of the data [29]. The content analysis was conducted according to issues highlighted by Burla et al. [30] and Elo et al. [31] to improve the reliability of the analysis. The limitation of this study is that it focuses on the sustainability disclosures of the companies. Further studies including surveys and case analysis can be conducted to explore the sustainability practices of textile and apparel companies in Turkey.

\section{RESULTS AND DISCUSSION}

This section discusses the results from the content analysis of the sustainability disclosures of textile and apparel companies. The first part of the research determined the GRI topic-specific standards, related keywords and phrases. The frequency results of the keywords and phrases are reported in the last column of Table 3 . The italicized words represent more general and comprehensive concepts related to GRI standards. There were 6 topic-specific standards related to economic issues, 8 topic-specific standards related to environmental issues and 19 topic-specific standards related to social issues. According to the results, general and comprehensive keywords (italic words) were more frequent than topic-specific keywords. For instance, the frequency of employee was 7 , which means it was repeated more than 1,500 times while the frequency of water was 5 (repeated between 1,000 and 1,249 times). The frequencies of employee right / benefits, and customer and product were 4 (repeated between 750 and 999 times). The frequencies of market, supplier and education were 3 (repeated between 500 and 749 times). The frequencies of economic, energy, waste, community and public were 2 (repeated between 250 and 499 times). The frequencies of other keywords and phrases included in the analysis were 1 (repeated between 0 and 249 times).

The second part of the research analyzed the percentages of companies disclosing GRI economic, environmental and social standards, according to the occurrences of the keywords given above. Figure 1, which presents the percentages of companies disclosing GRI economic standards, shows that a majority of the companies had sustainability disclosures about economic performance (74\%) and anti-competition (65\%). In contrast, only a few companies made disclosures about anti-corruption (29\%). Figure 2, which presents the percentages of companies disclosing GRI environmental standards, shows that a large proportion of the companies made sustainability disclosures about water and effluents (82\%) followed by energy $(68 \%)$ and supplier environmental assessment (62\%). However, only $12 \%$ made disclosures about environmental compliance. Figure 3, which presents the percentages of companies disclosing GRI social standards, shows that most companies made sustainability disclosures about training and education (88\%), and employment (85\%) while $74 \%$ made disclosures about occupational health and safety, diversity and equal opportunity, marketing and labeling. In contrast, none made disclosures about supplier social assessment and socioeconomic compliance.

Table 3. Frequency of selected issues in the sustainability disclosures of Turkish Textile and Apparel companies*

\begin{tabular}{|c|c|c|}
\hline GRI Code & Topic specific standards & Frequency of GRI topic specific keywords** \\
\hline GRI 201 & Economic performance & economic (2), direct economic (1), climate (1), benefit plan (1), financial assistance (1) \\
\hline GRI 202 & Market presence & market (3), entry level wage (1), local senior manager (1) \\
\hline GRI 203 & Indirect economic impacts & infrastructure (1), indirect economic (1) \\
\hline GRI 204 & Procurement practices & local supplier (1) \\
\hline GRI 205 & Anti-corruption & corruption / bribery (1), anti-corruption policies, (1), incidents of corruption (1) \\
\hline GRI 206 & Anti-competitive behavior & competition (1), anti-competitive behavior (1), trust (1), monopoly (1) \\
\hline GRI 301 & Materials & weight/volume (1), recycled input (1), reclaimed product (1) \\
\hline GRI 302 & Energy & $\begin{array}{l}\text { energy (2), internal energy consumption (1), external energy consumption (1), energy } \\
\text { intensity (1), energy reduction (1), energy reduction of products (1) }\end{array}$ \\
\hline GRI 303 & Water and effluents & water (5), water withdrawal (1), water discharge (1), water consumption (1) \\
\hline GRI 304 & Biodiversity & $\begin{array}{l}\text { protected area (1), impact of activities and products (1), protected habitat (1), red list } \\
\text { species (1) }\end{array}$ \\
\hline GRI 305 & Emissions & $\begin{array}{l}\text { Direct greenhouse gas (GHG) emissions (1), energy indirect GHG emissions (1), other } \\
\text { indirect GHG emissions (1), GHG emission intensity (1), reduction of GHG emissions } \\
\text { (1), emission of ozone depleting substances (1), nitrogen oxide, sulfur oxide, other } \\
\text { airborne emissions (1) }\end{array}$ \\
\hline GRI 306 & Effluents and waste & $\begin{array}{l}\text { effluent (1), waste (2), water discharge quality and destination (1), waste type and } \\
\text { disposal method (1), significant pills (1), transport of hazardous waste (1), affected } \\
\text { water bodies (1) }\end{array}$ \\
\hline GRI 307 & Environmental compliance & non-compliance with environmental laws and regulations (1) \\
\hline GRI 308 & $\begin{array}{l}\text { Supplier environmental } \\
\text { assessment }\end{array}$ & $\begin{array}{l}\text { supplier (3), selecting new suppliers using environmental criteria (1), negative } \\
\text { environmental impacts on supply chain (1) }\end{array}$ \\
\hline
\end{tabular}

Table 3. Continued 


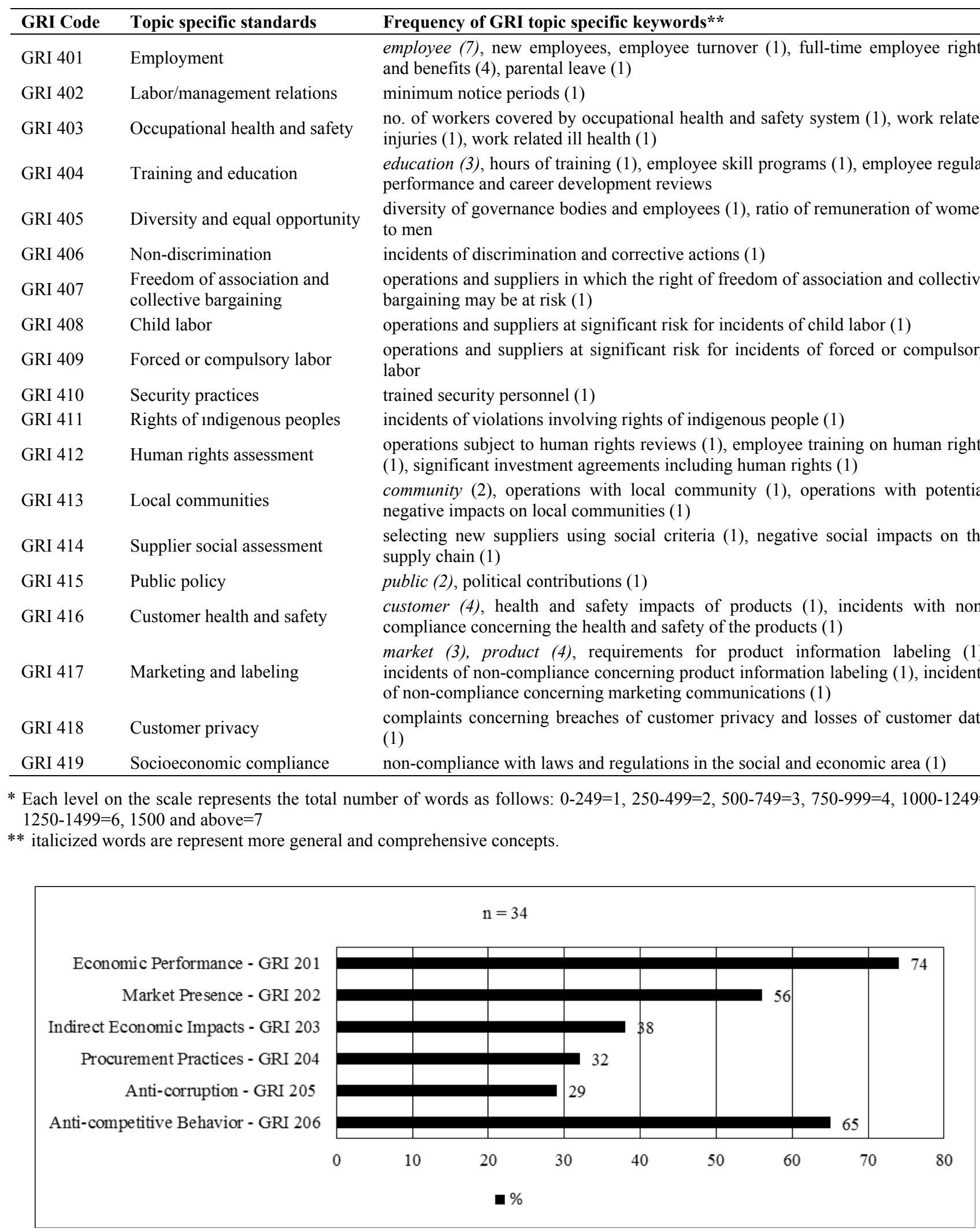

Figure 1. Percentages of companies disclosing GRI Economic Standards 


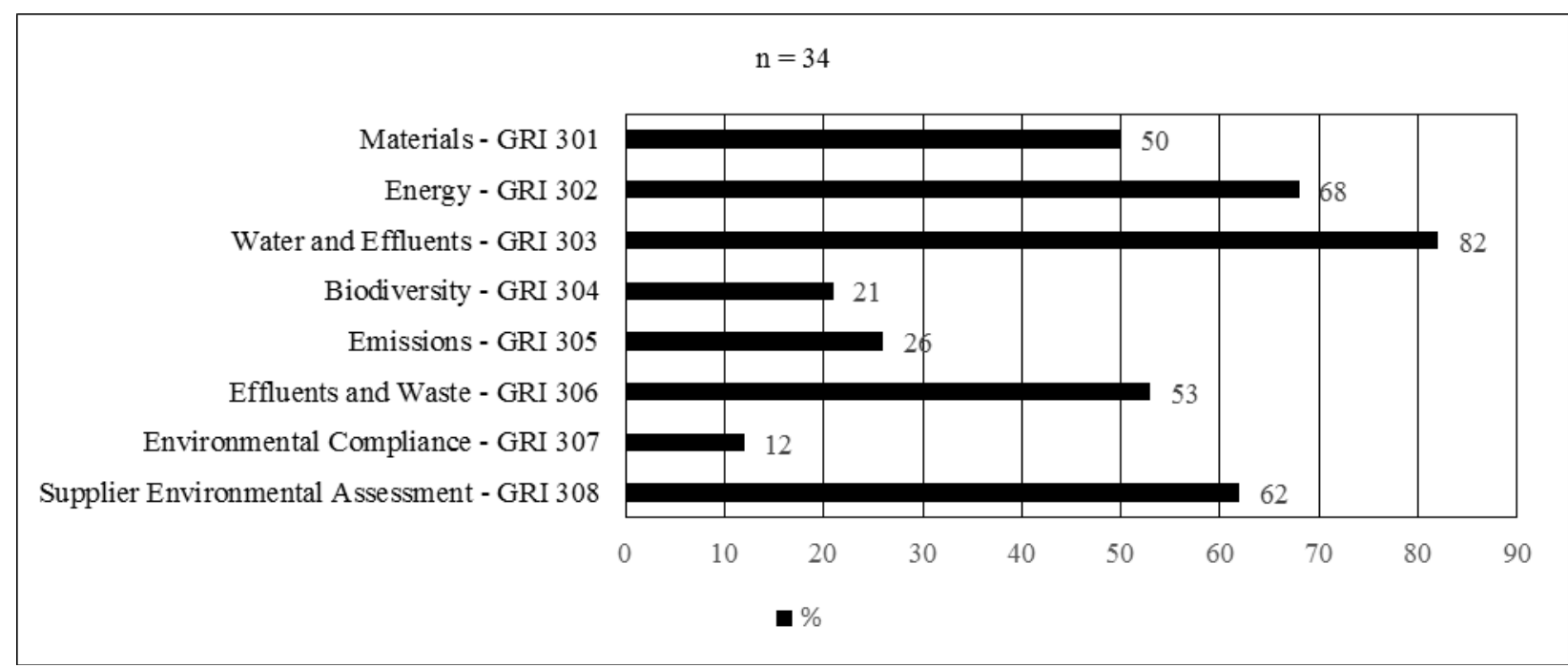

Figure 2. Percentages of companies disclosing GRI Environmental Standards

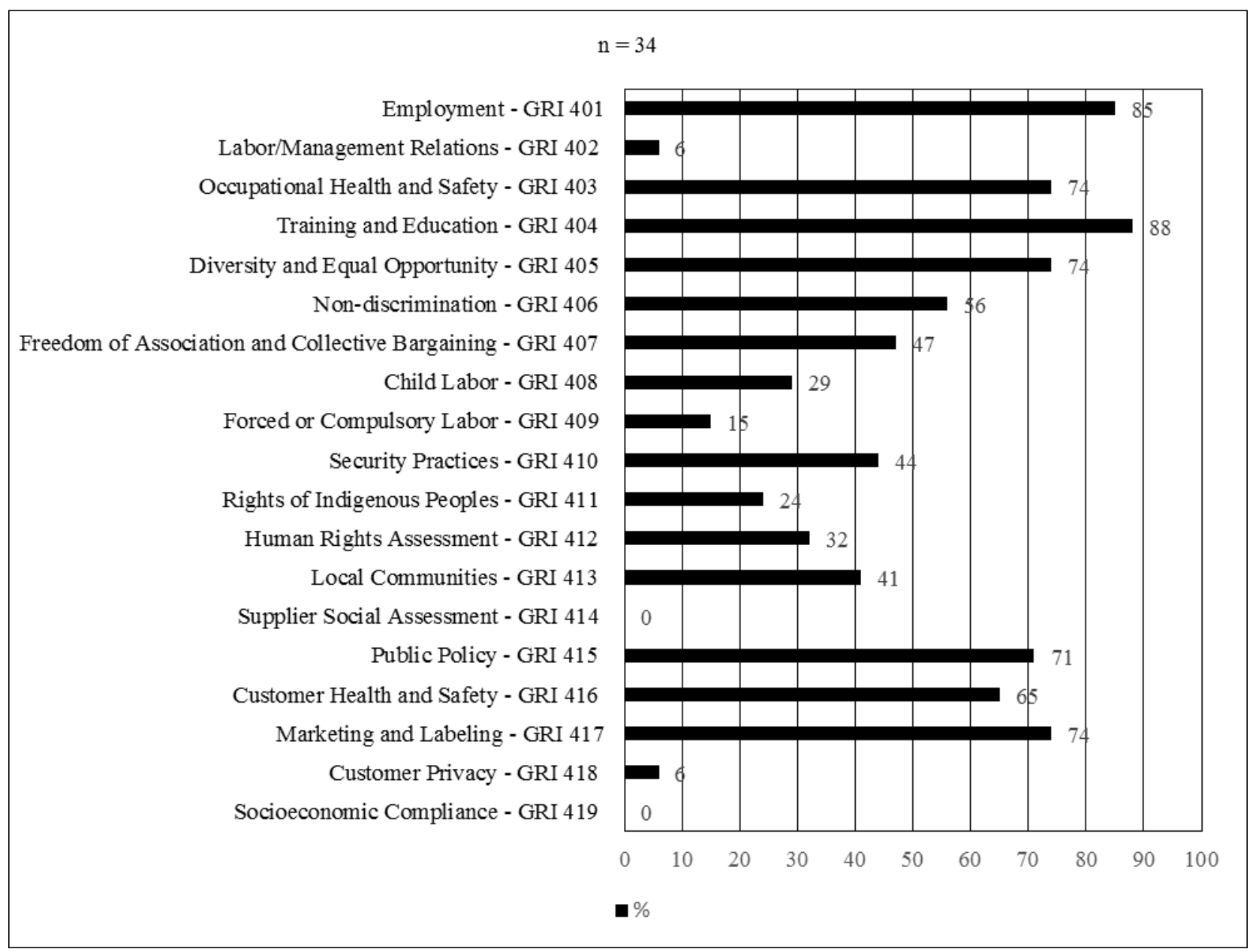

Figure 3. Percentages of companies disclosing GRI Social Standards

\section{CONCLUSION}

There is a rising trend in discussions about sustainability issues in the textile and apparel industry because environmental and social sustainability applications will inevitably have a significant effect on economic sustainability at both the micro and macro level. More recyclable and/or renewable as well as health and environment-friendly types of raw materials provided by innovative scientific and technological research, such as manufactured fibers instead of cotton, are expected to be used by textile and apparel companies to promote sustainability. Innovative studies in the textile industry are expected to focus on methods for more efficient production 
and use of manufactured fibers due to the factors explained previously. Capital investment and expenditure will most likely shift to focus on modernized, more efficient and fully-automated production systems, enabling the option of customized production through 3D technologies, more effective environmental management and protection systems as well as more efficient resource planning systems with minimized/eliminated usage of harmful chemicals. Innovative technologies are also expected to enable regional and even personalized product lines to be produced through fully automated 3D and similar technologies. The bottom line in supplier selection should be looking for those with lesser footprints and open to mutually beneficial and sustainable relationships through transparency and control. Cost considerations should be treated carefully, yet at a lower level of importance, since additional costs incurred for purpose of sustainability will be offset by increased demand and sales and/or other longer-term benefits. Complying with standards and regulations regarding sustainability, as well as improving them by internal practices, are believed not only to promote sustainability but also to increase operational effectiveness and efficiency. Competitive activities and operational efficiency are concentrated around innovative methods of producing longer-lasting products requiring fewer washing and cleaning processes.

The results of the analysis reveal that approximately $18 \%$ of textile and apparel companies in Turkey currently provide sustainability disclosures. The GRI issues emphasized most concern employees, and water, followed by employee rights, product, market, suppliers, education, the economy, energy, waste, the community and the public. Wide variations were observed in GRI topic-specific disclosures, including economic, environmental and social topics. A majority of the sampled companies disclosed economic issues, including economic performance and anticompetition, although only a few provided disclosures about anti-corruption. A large proportion of the companies provided environmental disclosures about water and effluents, and energy whereas few provided disclosures about environmental compliance. Social sustainability disclosures, including training, education and employment, were provided by most companies. Finally, a number of companies provided disclosures about occupational health and safety, diversity and equal opportunity, marketing and labeling. However, made disclosures about supplier social assessment and socioeconomic compliance.

\section{REFERENCES}

1. Ufuk 2030. 2016, September 16. Retrieved from https:// tgsd.org.tr/ assets/2017/ufuk2030baski26.09.16.pdf (Accessed July 30, 2018).

2. Better Cotton Initiative. 2018. What makes BCI and Better Cotton unique? Retrieved from https://bettercotton.org/resources/message/ (Accessed July 25, 2018).

3. Turley DB, Copeland JE, Horne M, Blackburn RS, Stott E, Laybourn SR, Harwood J, Hughes JK. 2009. The role and business case for existing and emerging fibres in sustainable clothing: Final report to the department for environment, food and rural affairs (Defra), London, UK.

4. Fletcher K. 2013. Sustainable fashion and textiles: design journeys Greenpeace, hazardous chemicals in branded luxury textile products on sale during, 16.

5. Morley NJ, Bartlett C, McGill I. 2009. Maximising reuse and recycling of UK clothing and textiles: A report to the department for environment, food and rural affairs. Oakdene Hollins Ltd, London: Defra.

6. Scott G. 2018. The higg index. Retrieved from https://apparelcoalition.org/the-higg-index/ (Accessed June 13, 2018).

7. Goworek H, Fisher T, Cooper T, Woodward S, Hiller A. 2012. The sustainable clothing market: An evaluation of potential strategies for UK retailers International Journal of Retail \& Distribution Management 40(12), 935-955.

8. Jones P, Comfort D, Hillier D. 2010. Sustainability in the global shop window International Journal of Retail \& Distribution Management 33(12), 882-92.

9. Wced SWS. 1987. World commission on environment and development. Oxford University Press, Oxford, UK.

10. Alkaya E, Demirer GN. 2014. Sustainable textile production: A case study from a woven fabric manufacturing mill in Turkey Journal of Cleaner Production 65, 595-603.

11. Pulat E, Etemoglu AB, Can M. 2009. Waste-heat recovery potential in Turkish textile industry: Case study for city of Bursa Renewable and Sustainable Energy Reviews 13(3), 663-672.
12. Eser B, Celik P, Cay A, Akgumus D. 2016. Tekstil ve konfeksiyon sektorunde surdurulebilirlik ve geri donusum olanaklari Tekstil ve Muhendis 23, 101.

13. Guyer GT, Nadeem K, Dizge N. 2016. Recycling of pad-batch washing textile wastewater through advanced oxidation processes and its reusability assessment for Turkish textile industry Journal of Cleaner Production 139, 488-494.

14. Ar AA, Tokol T. 2010. Tekstil sektorundeki 1sletmelerin yesil pazarlamadan kaynakli kazanimlari Elektronik Sosyal Bilimler Dergisi 9(31), 148-168.

15. Kusku F. 2007. From necessity to responsibility: Evidence for corporate environmental citizenship activities from a developing country perspective Corporate Social Responsibility and Environmental Management 14(2), 74-87.

16. Kamal Y, Deegan C. 2013. Corporate social and environment - related governance disclosure practices in the textile and garment industry: Evidence from a developing country Australian Accounting Review 23(2), 117-134.

17. Kozlowski A, Searcy C, Bardecki M. 2015. Corporate sustainability reporting in the apparel industry: An analysis of indicators disclosed International Journal of Productivity and Performance Management 64(3), 377-397.

18. Steurer R, Langer ME, Konrad A, Martinuzzi A. 2005. Corporations, stakeholders and sustainable development I: A theoretical exploration of business-society relations Journal of Business Ethics 61(3), 263281.

19. Roca LC, Searcy C. 2012. An analysis of indicators disclosed in corporate sustainability reports Journal of Cleaner Production 20(1), 103-118.

20. Empowering Sustainable Decisions. 2018. March 08 GRI Standards. Retrieved from https://www.globalreporting.org/standards/ (Accessed April 25, 2018).

21. Belal AR. 2016. Corporate social responsibility reporting in developing countries: The case of Bangladesh. Routledge. 
22. Lozano R. 2013. Sustainability inter-linkages in reporting vindicated A study of European companies Journal of Cleaner Production 51, 57-65.

23. Asif M, Searcy C, Santos PD, Kensah D. 2013. A review of Dutch corporate sustainable development reports Corporate Social Responsibility and Environmental Management 20(6), 321-339.

24. Gallego I. 2006. The use of economic, social and environmental indicators as a measure of sustainable development in Spain Corporate Social Responsibility and Environmental Management 13(2), 78-97.

25. Skouloudis A, Evangelinos KI. 2009. Sustainability reporting in Greece: Are we there yet? Environmental Quality Management 19(1), 43-60.

26. Krippendorff K. 2004. Content analysis: An introduction to its methodology. Sage, Thousand Oaks, CA.
27. İstanbul Sanayi Odası. 2017. Türkiye'nin 500 büyük sanayi kuruluşu 2017. Retrieved from http://www.iso500.org.tr/500-buyuk-sanayikurulusu/2017/?ara=\&year=2017\&sayfa $=2$ (Accessed June 15, 2018).

28. KAP. 2018. Merkezi kayit istanbul. Retrieved from https://www.kap.org.tr/en/Endeksler (Accessed June 15, 2018).

29. White, MD, Marsh, EE. 2006. Content analysis: A flexible methodology Library Trends 55(1), 22-45.

30. Burla L, Knierim B, Barth KL, Duetz M, Abel T. 2008. From the text to coding: Intercoder reliability assessment in qualitative content analysis Nursing Research 57, 113-117.

31. Elo S, Kääriäinen M, Kanste O, Pölkki T, Utriainen K, Kyngäs H. 2014. Qualitative content analysis: A focus on trustworthiness $S A G E$ open 4(1), 1-10.

Appendix 1. Descriptions of Abbreviations

International Organization for Standardization : ISO

Global Reporting Initiative

: GRI

International Association for Research and Testing in

the Field of Textile and Leather Ecology

Occupational Health and Safety Management Systems

Global Organic Textile Standard

Uster Textile Quality Control Technologies

Autocoro Yarn Quality Certification

Certification of Environmental Standards

: OEKO-TEX

: OHSAS

: GOTS

: USTER

International Sleep Products Association

: BELCORO

Leadership in Energy and Environmental Design

: CERES

: ISPA

: LEED 